\title{
„NE GONDOLJ A FEHÉR MEDVÉRE!” AZ EMLÉKEZETI GÁTLÁS NEUROPSZICHOLÓGIÁJA
}

\author{
RACSMÁNY MIHÁLY \\ Szegedi Tudományegyetem, Pszichológia Tanszék, Szeged \\ University of Bristol, Department of Experimental Psychology, Bristol \\ E-mail: racsmany@edpsy.u-szeged.hu
}

SZENDI ISTVÁN

Szegedi Tudományegyetem, Pszichiátriai Klinika, Szeged

E-mail: istvanszendi@nepsy.szote.u-szeged.hu

\begin{abstract}
A tanulmány áttekinti a végrehajtó funkciók vizsgálata során felmerülő elméleti problémákat és kísérletet tesz annak felvázolására, hogy milyen lehetséges szerepet játszik az emlékezeti gátlás a flexibilis tervezésben és feladatmegoldásban. Részletesen tárgyalja a kísérleti emlékezetkutatásban széles körben használt emlékezeti gátló paradigmákat, az irányított felejtést, a gondolatelnyomást, az elóhívás kiváltotta gátlást, és bemutatja, hogyan hasznosithatóak ezek az eljárások a kognitív neuropszichológiai vizsgálatoknál. Tanulmányunkban bemutatjuk, milyen patológiás következménye lehet az emlékezeti gátlás károsodásának depresszióban, poszttraumás zavarban és pánikrohamban szenvedö betegeknél. Végül pedig az automatikus emlékezeti gátló folyamatok épsége mellett az intencionális emlékezeti gátlás zavarát demonstráljuk szkizofrén személyeknél.
\end{abstract}

Kulcsszavak: végrehajtó funkciók, munkamemória, prefrontális kéreg, emlékezeti gátlás, szkizofrénia

A kísérleti emlékezetkutatás elmúlt száz évében a gátlás fogalma időről időre felbukkant, hogy azután rövid tündöklés után újra évtizedekig a feledés homályába vesszen. Kezdetben a felejtéssel kapcsolatos elméleti munkák, elsősorban az interferencia-elmélet hívei használták, ső́t a gátló folyamatok számítottak az első igazán átfogó interferencia-elmélet legfontosabb magyarázóelvének (MCGEOCH, 1936; 1942). A magyar pszichológiai irodalomban ettől függetlenül is fontos szerepet 
kapott Ranschburg Pál emlékezeti vizsgálatainak köszönhetően (lásd CzIGLER, 1988; 2000; jelen kötetben tárgyalják NÉMETH, RACSMÁNY, KóNYA, PléH a 403415. [33-45.] oldalon). Később a gátlás mint magyarázó fogalom elsősorban a tanulással kapcsolatos irodalomban bukkant fel, majd a hetvenes években vált ismét népszerűvé John Anderson és Gordon Bower nagy karriert befutott HAM (HAM Human Associative Memory) modelljének köszönhetően (ANDERSON, BOWER, 1973). A nyolcvanas években a PDP (Parallel Distributed Processing) modellek térnyerése révén a gátlás ismét központi magyarázó elvvé vált az emlékezeti irodalomban (MCCLELLAND, 1988; MCCLELLAND, RUMELHART, 1986), majd az 1990es években a kognitív idegtudomány megizmosodásával az idegrendszeri analógiát szem előtt tartó emlékezeti modellek ismét divatba hozzák (vö. ANDERSON, NEELY, 1996). A neuropszichológiai kutatás számára azonban némileg eltérő úton vált érdekessé az emlékezetben megvalósuló gátló folyamatok mechanizmusának kérdése, nevezetesen a frontális lebeny sérülésének következtében létrejövő munkamemória-zavarok kapcsán.

\section{VÉGREHAJTÓ FUNKCIÓK ÉS A FRONTÁLIS LEBENY SÉRÜLÉSE}

Az emlékezeti irodalom egyik nagy hatású modellje szerint (BADDELEY, 1986; BADDELEY, HITCH, 1974) a rövid távú emlékezetet munkamemóriaként kell felfogni, olyan rendszerként, amely fenntartja és manipulálja az információt a következtetést, megértést, tanulást igénylő feladatok kivitelezése alatt. A modell szerint a munkamemória három komponensből áll, két alrendszerből, amelyek a verbális és a téri-vizuális információ fenntartásáért és manipulációjáért felelősek, valamint egy központi végrehajtónak nevezett rendszerből, amely megteremti az összeköttetést az alrendszerek között. A munkamemória-modell elképzelése szerint a központi végrehajtó működése nélkül a kognitív működést kizárólag az alacsonyabb szintű viselkedéses és gondolati sémák versengése határozná meg, vagyis a viselkedésből hiányozna a hatékony tervezés, a flexibilis működés és a végrehajtott részfolyamatok állandó monitorozása (NORMAN, SHALliCE, 1986; SHALliCE, 1982; 1988; SHALlice, BuRGESS, 1998). A végrehajtó funkciók kutatásának karriertörténetében mérföldkőnek számított az a felismerés, hogy a laboratóriumokban produkált kísérletek és a frontális sérültekkel kapcsolatos klinikai megfigyelések meglehetősen hasonló jelenségekkel foglalkoznak. LURIJA (1973) elképzelése szerint ugyanis a frontális lebeny a székhelye a viselkedés programozására, szabályozására és az akciók igazolására specializálódott rendszernek. A frontális lebeny szindróma klasszikus tünetei a viselkedési rigiditás, az elterelhetőség, a perszeveráció, a flexibilis tervezés és kivitelezés zavarai és az új helyzetekkel való megküzdés terén jelentkező problémák terminusaiban ragadhatók meg (például GOLDSTEIN, 1939; ESLinger, DAMASio, 1985; RYlander, 1939; Shallice, Burgess, 1991). A kísérleti és neuropszichológiai adatok alapján úgy tűnik, hogy a végrehajtó funkciók működésére van szükség:

1. A tervezést és döntést igényelő feladatoknál.

2. A hibák felismeréséhez és kijavításához. 
3. Azokban a helyzetekben, ahol teljesen új vagy nem túltanult viselkedést kell produkálni.

4. Veszélyes vagy a kivitelezés szempontjából nehéz helyzetekben.

5. Olyan helyzetekben, ahol a már kialakult szokások ellenében kell cselekedni (BURGESS, 1997).

A fenti felsorolásnak megfelelően a végrehajtó funkciók leggyakrabban használt vizsgálóeljárásai a flexibilis tervezés, a stratégiaváltás és a monitorozási műveletek épségét hivatottak feltérképezni. Ilyen széles körben használt vizsgálóeljárások a különféle útvesztők (Porteus, Elithorn), a fluenciafeladatok, a Wisconsin kártyaszortírozási feladat, a Toronyfeladatok (Hanoi, London, Toronto), és a Végrehajtó funkciók zavarait vizsgáló viselkedéses eljárások (Behavioural Assessment of the Dysexecutive Syndrome - BADS; Wilson, Alderman, Burgess, Evans, 1996).

A végrehajtó működés zavarait vizsgáló feladatokkal kapcsolatos legnagyobb probléma, hogy túl sok azonosítatlan kognitív folyamatot mérnek. Azért kell lézió alapján (frontális sérülés) válogatni a betegeket, mert a végrehajtó működés zavara nem operacionális, hanem elméleti meghatározás, tehát nem létezik a végrehajtó funkciók sérülését mérő szürő eljárás (BURGESS, 1997; SHALlice, BuRGESS, 1998). Valójában sokszor még a terminus megfelelő használata körül is zavar van, a végrehajtó működés (executive function) következő jelentései fordulnak elő a szakirodalomban: problémamegoldás (LEVIN, GOLDSTEIN, WILLIAMS, EISENBERG, 1991), tervezés (SHALLICE, 1982), viselkedés (aktivitás) kezdeményezése (BURGESS, Shallice, 1996; Shimamura, JanOWSKy, SWUiRe, 1991), kognitív becslés (SHALliCE, EVANS, 1978), prospektív emlékezet (COCKBURN, 1995; SHIMAMURA, 1989).

Mindezeket figyelembe véve úgy tűnik, megérett a helyzet a végrehajtó működés vagy - a munkamemória-modell koncepciójának megfelelően - a központi végrehajtó felbontására több, jobban azonosítható komponensre. Az egyik ilyen lehetséges komponens a tervezés és a végrehajtás közben megvalósuló emlékezeti gátlás vagy emlékezeti frissítés lehet (Roberts, HAGER, Heron, 1994; SHIMAMURA, 1995). Ezt támasztja alá, hogy frontális sérülésnél fokozott érzékenység jelentkezik az interferenciára (Milner, 1963; 1964; SHImamura, 1995). Perszeveratív hibák jellemzik a torony- (GLOSSER, GOODGLAS, 1990), valamint a fluenciafeladatok megoldását (BALDO, SHIMAMURA, 1998). Megnövekedett interferencia tapasztalható továbbá a Go-No-Go feladatnál (LEIMKUHLER, MEsUAM, 1985), a Brown-Peterson-feladatnál (Stuss, Alexander, Hamer, Palumbo, Dempster, BINNS, LEVINE, IZUKAWA, 1998) és páros-asszociációs feladatoknál (SHIMAMURA, JANOWSKY, SWUIRE, 1991). A helyzetet persze bonyolítja, hogy vannak, akik csak bizonyos feladatoknál kapnak megnövekedett interferenciát, STUSS (1991) például orbito-frontális sérülteknél magasabb interferenciát tapasztalt a Brown-Petersonfeladatnál, viszont nem kapott ilyen hatást a Stroop-paradigma esetében.

SHIMAMURA (1995) elképzelése szerint a frontális sérülteknél jelentkező végrehajtó működésbeli zavarok hátterében a gátló kontroll kiesése áll. A személy nem képes gátolni a külső vagy belső ingerek által aktivált irreleváns vagy hibás keresési stratégiákat. E szerint ugyancsak a gátlás útján megvalósuló emlékezeti frissítés lenne a felelős a frontális sérülésnél fellépő konfabulációért (BENSON, STUSS, 
1990), valamint a szabad felidézésnél betolakodó gyakori hibákért is (METzLER, PARKIN, 2000). Mindezzel egybevág, hogy ROBERTS és munkatársai (1994) kísérleti módszerekkel három munkamemória-komponenst azonosítottak: manipuláció és monitorozás; fenntartó funkció és gátlás. Úgy tűnik tehát, hogy az emlékezeti gátló folyamatok alapvető szerepet játszanak a végrehajtó funkciók működésében, mivel pedig a kísérleti emlékezetkutatás jó néhány vizsgálati módszert kidolgozott az emlékezeti gátlás vizsgálatára, ezek mủködésének beható elemzése döntően hozzájárulhat a végrehajtó rendszer komponenseinek azonosításához.

\section{AZ EMLÉKEZETI GÁTLÁS KÍSÉRLETI VIZSGÁLÓELJÁRÁSAI}

Megismerő rendszerünknek nemcsak a releváns információk fenntartását és szervezését, de a már nem aktuális, irreleváns információk kiszorítását is meg kell oldania. Nem arra a helyre kell emlékeznünk, ahol tegnap parkoltunk, hanem ahol ma áll az autónk, nem a régi telefonszámunkat és lakáscímünket kell felidéznünk, hanem a jelenlegit. Az irányított felejtésnek nevezett kísérleti paradigma pontosan ezt az emlékezeti frissítési helyzetet modellezi (BJORK, 1989). Az irányított felejtésnek több változata is létezik, de az emlékezeti gátlás szempontjából az úgynevezett listás eljárás a releváns, így csak ezt tárgyaljuk (BASDEN B. H., BASDEN, D. R., 1996; 1998; BASDEN, B. H., BASDEN, D. R., GARGANO, 1993). Ennél a kísérleti eljárásnál a vizsgálati személy először egy szólistát tanul, majd olyan instrukciót kap, hogy az eddig tanult szavakat elfelejtheti, mert azok csak gyakorlásra szolgáltak, ezt követően pedig egy második lista szavait memorizálja. Később a felidézésnél a kísérletvezető persze álnok módon az első lista szavait is kéri a vizsgálati személytől.

Számos kísérletben kimutatták, hogy az első lista után adott felejtési instrukció hatására a vizsgálati személy ezekből a szavakból valóban sokkal kevesebbet tud felidézni, mint a kontrollcsoport tagjai, akik nem kaptak felejtési instrukciót az első lista után (BJORK, LaBerge, Legrand, 1968; BJORK, 1970; Paller, 1990; RUSSO, ANDRADE, 1995; WEINER, REED, 1969). Meglepő eredmény, hogy a felejtési instrukció hatására a második listára sokkal jobban emlékeznek a vizsgálati személyek, úgy tűnik, mintha az első lista szavainak zavaró, interferáló hatása megszűnt volna, mintha tényleg elfelejtették volna őket. De vajon tényleg elfelejtették őket a vizsgálati személyek? Úgy tűnik, nem ez a helyzet, mert ha nem felidézési, hanem felismerési feladatot adunk, az első listával kapcsolatos felismerési teljesítmény nem különbözik a második listával kapcsolatban produkált teljesítménytől. Az első lista szavai tehát nem tűntek el a vizsgálati személy fejéből vagy munkamemóriájából, de a felejtési instrukció hatására gátlás alá kerültek. A gátlás meglétét támasztja alá az a tény is, hogy a vizsgálati személyek akkor sem tudják felidézni a felejtési instrukció előtt tanult szavakat, ha erre felszólítják őket vagy jutalmat kapnak minden felidézett első listán szereplő szóért (WOODWARD, BJORK, 1971; WOODWARD, BJORK, JONGEWARD, 1973). Úgy tűnik tehát, hogy képesek vagyunk adott helyzetben, a sikeres feladatmegoldás érdekében szándékosan gátlás alá helyezni munkamemóriánk aktuális tartalmát. Ezáltal csökkentjük a mun- 
kamemóriában még jelenlévő, de az adott feladat szempontjából irreleváns információ interferáló hatását. A gátlás zavart szenvedhet, és így a felejtésre ítélt információk betolakodhatnak, ha a második lista tanulása alatt, tehát a felejtési instrukció után a munkamemóriát túlterheljük valamilyen másodlagos feladattal (CONWAY, HARries, NOYES, RACSMÁNy, FrANkish, 2000), ami arra utal, hogy a gátlási kapacitás egyik meghatározó tényezője és egyben indikátora is a munkamemória kapacitásának.

Létezik egy másik kísérleti paradigma is, amely során a vizsgálati személynek szándékosan ki kell szorítania bizonyos képzeteket a munkamemóriájából. Ezt az eljárást megalkotója, Daniel Wegner gondolatelnyomásnak (thought suppression) nevezte el (WEGNER, 1989; 1994; WENZLAFF, WEGNER, ROPER, 1988; WENZLAFF, WEGNER, KLEIN, 1991). Az eljárás során a vizsgálati személynek öt percen keresztül nem szabad egy fehér medvére gondolnia, amennyiben ez mégis bekövetkezne, ezt jeleznie kell a vizsgálatvezetőnek. Ezt követően újabb öt percen keresztül olyan gyakran kell egy fehér medvére gondolnia, amilyen gyakran csak tud. A kísérletek eredménye szerint minél kevesebbszer tolakodott be valakinél a fehér medve a gondolatkiszorítási helyzetben, annál többször és részletesebben fog később eszébe jutni, a gátlás alóli kioldódás következtében egy visszacsapási hatás lép fel. Az irányított felejtés és a gondolatelnyomás technikája számos ponton eltér egymástól, egyben azonban megegyeznek, a gátlást a személy mindkét esetben intencionálisan indítja el. Vannak azonban olyan emlékezeti helyzetek is, ahol a gátlás automatikusan megy végbe.

Napjaink talán legtöbbet vizsgált emlékezeti gátló paradigmáját, az elóhívás kiváltotta gátlást Michael Anderson és munkatársai dolgozták ki (ANDERSON, BJORK, E. L., BJORK, R. A., 1994), az eljárás előzményei azonban a hatvanas évek interferencia-irodalmában lelhetőek fel - elsősorban a Norman SLAMECKA (1968) nevéhez fűződő részleges készletgátlás jelenségben, ahol a kísérleti személyek öt percen keresztül egy adott készletbe tartozó szavakat, például európai országneveket tanulnak, ezt követően pedig annyi európai országnevet kell felidézniük, amenynyit csak tudnak. A klasszikus eredmények szerint a készlet egy részének előzetes tanulása miatt a készlet más elemei - tehát például azoknak az országoknak a nevei, amelyeket korábban nem tanultak - lényegesen kisebb valószínűséggel jutnak majd a kísérleti személyek eszébe, összehasonlítva a kontrollcsoport teljesítményével, akik korábban egyáltalán nem memorizálták az országneveket (SLAMECKA, 1968; 1972; 1975). A klasszikus magyarázat szerint a nem tanult elemek felidézése azért károsodott, mert az azonos csoportba - így azonos hívóingerhez - tartozó más elemek gyakorlása révén gátlás alá kerültek. Az előhívás kiváltotta gátlás paradigmája hasonló elvekre épül, a vizsgálati személyek először kategóriamintapéldány párokat tanulnak (például BÚTOR-ASZTAL), majd bizonyos kategóriákból bizonyos mintapéldányokat gyakorolnak oly módon, hogy a mintapéldány első két kezdőbetűjét kell kiegészíteni (például BÚTOR-ASZ...).

Igy tehát lesznek olyan elemek, amelyeket gyakoroltak, lesznek olyan elemek, amelyeknek a kategóriájából más szavakat gyakoroltak, de őket magukat nem (például BÚTOR-SZEKRÉNY), és lesznek olyan szavak, amelyeket szintén nem gyakoroltak, de a kategóriájukból más szavakat sem (például GYÜMÖLCS-SZÖ- 
LŐ). Számos vizsgálat egybehangzó eredménye, hogy a vizsgálati személyek azokat az elemeket, amelyeknek a kategóriájából más elemeket gyakoroltak (de őket magukat nem), szignifikánsan gyengébben idézik fel, mint azokat a nem gyakorolt elemeket, amelyeknek a kategóriájából más elemeket sem gyakoroltak (ANDERSON, BJORK, E. L., BJORK, R. A., 1994; ANDERSON, BJORK, 1994; ANDERSON, Neely, 1996; ANderson, SPEllman, 1995). Ez Anderson és munkatársai szerint a gátlás bizonyítéka, hiszen a különbséget pusztán az okozza, hogy egyes nem gyakorolt elemek kategóriájából más szavakat gyakoroltak. A részleges készletgátlás és az előhívás kiváltotta gátlás kitűnő példái az automatikusan megvalósuló emlékezeti gátlásnak, annak a mechanizmusnak, ahogyan a munkamemória tartalmának bizonyos része gátlás alá kerül az interferencia hatásainak csökkentése érdekében. Az emlékezeti frissítés elengedhetetlen a megismerő folyamatok flexibilis működéséhez, ezt példázzák azok az esetek, amikor az emlékezeti gátlásban károsodás történik.

\section{AZ EMLÉKEZETI FRISSÍTÉS PATOLÓGIÁJA}

A feladatvégzéshez már nem szükséges, de a munkamemóriában még meglévő információk gátlás alá helyezésének készségében egészséges emberek között is nagy egyéni különbségek léteznek.

Gernsbacher és munkatársai számos vizsgálatban mutatták ki, hogy azok a kísérleti személyeik, akik sikeresen tudták gátlás alá helyezni munkamemóriájuk irreleváns tartalmát, sokkal jobb teljesítményt mutattak például bonyolult szövegek megértésénél (GERnSBACHER, 1990; GERnSBACHER, FAuST, 1991; GERnSbACHER, FAUST, 1995). Más vizsgálatok viszont arra hívják fel a figyelmet, hogy idős és fiatal személyek között szignifikáns különbség található az irreleváns információ kiszorításában (ZACKS, HASHER, 1994). Idős személyek lényegesen kevésbé tudják gátolni például egy mondat gyakori, de az adott helyzetben helytelen befejezését, kisebb felejtést produkálnak irányított felejtési helyzetben, mindennek következtében pedig a felidézési helyzetekben túl sok lényegtelen, sőt helytelen információ tolakodik be a helyes információk közé, ami lerontja emlékezeti teljesítményüket (HAmm, Hasher, 1992; Hartman, HaSher, 1991; ZaCks, HaSher, 1994). Mindez tehát alátámasztja, hogy az emlékezeti gátló kapacitásban meglévő egyéni különbségek jelentősen befolyásolhatják a megértési és emlékezeti teljesítményt. Az egészséges személyek egyéni különbségein túl léteznek olyan patológiás esetek is, amikor az emlékezeti gátlás károsodása a megismerő folyamatok zavarait idézi elő. Az egyik legismertebb eredmény, hogy depressziós betegek többnyire nem képesek kiszorítani, gátolni negatív gondolataikat (MATHEWS, MACLEOD, 1994; WENZLAFF, WEGNER, ROPER, 1988; WENZLAFF, WEGNER, KLEIN, 1991). Conway és munkatársainak eredményei szerint, ha egészséges és depressziós személyeknek 5 percig nem szabad a sikerre vagy a kudarcra gondolniuk, akkor a depressziós betegeknél szignifikánsan többet fognak betolakodni a kudarccal kapcsolatos gondolatok (CONWAY, HOWELl, GianNOPOUlOS, 1991). 
Az emlékezeti gátlás szempontjából szintén lényeges klinikai populációt alkotnak a kényszeres zavarban (DSM-IV, 1997) szenvedők. Ezeknél a betegeknél fö tünetnek számítanak az ismétlődően betolakodó gondolatok, amelyeket a beteg gyakran irracionálisnak érez, de megjelenésüket képtelen megakadályozni. A laboratóriumi vizsgálatok eredményei szerint az ilyen betegek irányított felejtési helyzetben, ahol a megtanulandó és elfelejtendő szavak negatív vagy pozitív jelentésűek lehettek, lényegesen több felejtésre ítélt negatív szót idéztek fel, mint az egészséges kontrollszemélyek (Wilhelm, MCNAlly, BAER, Florin, in press). Hasonló eredményeket kaptak pánikrohamban szenvedő betegeknél, akiknél gyakori a saját test károsodásával kapcsolatos intenzív gondolatok erőszakos betolakodása. Irányított felejtési helyzetben, ahol a tanulásra bemutatott szavak között olyan szavak is voltak, amelyek vegetatív állapotokra, fizikai rosszullétre vonatkoztak, a pánikbetegek szignifikánsan kisebb szándékos felejtést tudtak produkálni, mint a kontrollszemélyek. Az emlékezeti problémák másik kitüntetett klinikai csoportját a poszttraumás stressz zavarban (DSM-IV, 1997) szenvedő betegek alkotják (vö. SCHACTER, 1998). Ezek a betegek valamilyen korábbi megrázó esemény átélése miatt gyakran egészen kiterjedt epizódokra amnéziások lehetnek (WILliaMS, 1994). A traumatikus eseményt igen gyakran gyerekkorukban élik át az ilyen személyek, nagy többségben gondozójuk bántalmazza őket, mivel a traumát okozó személytől mind fizikailag, mind egzisztenciálisan függnek, mentálisan próbálnak kilépni a szituációból, ső́t gyakran bántalmazójuk ad nekik felejtésre vonatkozó instrukciókat (Cloitre, Cancienne, Brodsky, Dulit, Perry, 1996; FinkelHor, Browne, 1985; Herman, 1981; RuSSEl, 1986). A kísérleti eredmények szerint a gyerekkorukban traumatizált vizsgálati személyek lényegesen nagyobb irányított felejtési hatást produkáltak, úgy tűnik, hogy az évek során elsajátították a szándékos felejtés technikáját (CLOITRE, CANCIENNE, BRODSky, DuliT, PERRY, 1996). Vannak azonban olyan áldozatok is, akik később elsősorban a traumatikus emlékek ismételt betolakodásától szenvednek. MCNALLY és munkatársai (1996) olyan megerőszakolt nőkkel végeztek irányított felejtési kísérletet, akik képtelenek voltak megszabadulni a traumatikus élmény emlékeitől; a kontrollcsoportot olyan megerőszakolt nők alkották, akik nem szenvedtek a betolakodó emlékektől. A vizsgálat eredményei szerint a poszttraumás stressz szindrómát mutató megerőszakolt nők egyáltalán nem képesek irányított felejtést produkálni, függetlenül attól, hogy a listán szereplő szavak pozitív, negatív vagy semleges jelentésűek, sőt a poszttraumás csoport a negatív szavakra az összes többi szónál jobban emlékezett (MCNally, Metzger, Lasko, Pitman, 1996). Úgy tűnik, hogy ezeknél az áldozatoknál az emlékezeti gátlás általános károsodásáról van szó. Ehhez hasonló eredményeket kaptak olyan háborús veteránoknál, akik szintén a poszttraumás stresszzavar tüneteit mutatták, rossz emlékezeti gátlásuk következtében tanulási helyzetekben igen nagy volt az interferencia hatása, ami károsodott hosszú távú tanulási teljesítményt idézett elő náluk (YeHUdA, KeEFE, HARveY, LEVENGOOD, GERBER, GENI, SIEVER, 1995). 


\section{INTENCIONÁLIS ÉS AUTOMATIKUS EMLÉKEZETI GÁTLÁS SZKIZOFRÉNIÁBAN}

Az emlékezeti gátló mechanizmusok szempontjából az egyik legérdekesebb klinikai csoportnak a szkizofrén betegek számítanak. Ennek egyik oka, hogy szkizofrén betegeknél számos vizsgálat szerint a végrehajtó müködések zavara figyelhető meg (Berman, Illowsky, Weinberger, 1988; Berman, Torrey, Daniel, WeinBerger, 1992; Callicott, Ramsey, Tallent, Bertolino, Knable, Coppola, GoldberG, VAN Gelderen, Mattay, Frank, MoOnen, Weinberger, 1998; Gold, Berman, RANDOlPh, GOldberG, Weinberger, 1996; Weinberger, BERMAN, 1998; WeINBERGER, BERMAN, ZECK, 1986). Sokan egyenesen úgy gondolják, hogy bizonyos szkizofrén tünetek hátterében a prefrontális kéreg zavara áll (lásd KéRI, JANKA, 1999; KéRI, JANKA, 2001; e kötetben tárgyalja SZABó JUdiT tanulmánya az 527-543. [157-173.] oldalon). Korábban láthattuk, hogy a frontális diszfunkciók vizsgálómódszereinél mutatott perszeveratív hibák egyik oka az emlékezeti gátlás mủködésének károsodása lehet. A szkizofrénia pozitív tünetei közül a gondolatbetolakodás, a hallucinációk és az inkoherens beszéd mind az emlékezeti gátló funkciók károsodását jelzik (FrITH, 1992, 1996). Az emlékezeti gátlás fogalmának tisztázásához elengedhetetlenül szükséges pontosítani a különböző gátló paradigmáknál működésbe lépő emlékezeti rendszerek természetét, valamint a különböző eljárások közötti eltéréseket és hasonlóságokat. Az emlékezeti gátló eljárásokat tárgyaló részben bemutattuk, hogy léteznek olyan eljárások, amelyekhez intencionálisan elindított gátlásra van szükség, más paradigmáknál viszont automatikusan megjelenik a gátló hatás. Feltételezésünk szerint szkizofrén betegeknél elsősorban az intencionálisan elindított gátlás zavarát lehet megfigyelni, éppen ezért a következőkben az intencionális és automatikus gátlás között meglévő különbségek illusztrációjaként röviden bemutatjuk egy jelenleg is folyó vizsgálatunk előzetes eredményeit (RACSMÁNY, SZENDI, CONWAY, 2001).

\section{SZKIZOFRÉN BETEGEK EMLÉKEZETI GÁTLÓ FOLYAMATAINAK VIZSGÁLATA}

\section{Vizsgálati személyek}

A vizsgálatban 15 szkizofrén beteg (7 férfi, 8 nő) vett részt, a vizsgálat idején valamennyien tünetmentesek. A szkizofrén csoport a Szegedi Tudományegyetem Pszichiátriai Klinikáján kezelt betegekből állt, valamennyien kezelőorvosaik diagnózisa alapján kerültek be a mintába (átlagos PANSS összpontszám $=50,2$ ). A szkizofrén betegek átlagos IQ (MAWI) pontszáma 105 (VQ = 112,8; PQ = 97,3), átlagos életkora 42,9 év ( $\mathrm{SD}=12,08)$. Előzetes vizsgálataink alapján valamennyi betegnek végrehajtó-működésbeli zavarai voltak, a Wisconsin kártyaszortírozási feladaton az átlagos perszeveratív hibák száma 22,9 $(\mathrm{SD}=10,2)$. 


\section{Eljárás}

A szkizofrén betegcsoport két kísérleti helyzetben vett részt. Az intencionális emlékezeti gátlás vizsgálatára az irányított felejtési paradigma korábban már ismertetett listás változatát választottuk, mivel ez napjainkban a legjobban feltárt emlékezeti gátló paradigma. A vizsgálati személyek két szólistát tanultak (7 szó/lista), a felejtési helyzetben a két lista között az első listára vonatkozó felejtési instrukciót kaptak, az emlékezési helyzetben ugyanezek a vizsgálati személyek az első listára vonatkozó emlékezési instrukciót kaptak. Az emlékezési és a felejtési helyzet sorrendje random módon változott az egyes kísérleti személyeknél.

A másik kísérleti helyzet a korábban már szintén ismertetett előhívás kiváltotta gátlás paradigmája volt, amivel az automatikus emlékezeti gátló folyamatokat kívántuk tesztelni. Az eljárás során a korábban már ismertetett sorrendben a vizsgálati személyek először kategória-mintapéldány párokat tanultak (10 kategória, 6 mintapéldány kategóriánként), ezt követően bizonyos kategóriákból bizonyos mintapéldányokat gyakoroltak, majd 10 perces késleltetést követően valamennyi kategória valamennyi elemét megkísérelték felidézni. A gyakorolt kategóriák és mintapéldányok véletlenszerủen variálódtak az egyes vizsgálati személyeknél.

\section{Eredmények}

Az irányított felejtési kísérlet eredményei az 1. táblázatban láthatók; ebből világosan látszik, hogy a szkizofrén betegek esetében nem jelentkezett emlékezeti gátlás. A statisztikai elemzéshez kétszempontos ANOVÁ-t használtunk, ahol a felejtési és emlékezési instrukciók képezték a csoportok közötti és az első, valamint a második listán mutatott felidézési teljesítmény a csoporton belüli változókat. Nincs szignifikáns különbség az emlékezési helyzetben az első és a második listák felidézési teljesítményében, és az emlékezési és felejtési instrukciót követően sincs szignifikáns különbség az első listák felidézési átlagában.

1. táblázat. Szkizofrén és egészséges személyekkel végzett irányított felejtés kísérletek felidézési eredményei

\begin{tabular}{|l|c|c|c|c|}
\cline { 2 - 5 } \multicolumn{1}{c|}{} & \multicolumn{2}{c|}{ Felejtési instrukció } & \multicolumn{2}{c|}{ Emlékezési instrukció } \\
\cline { 2 - 5 } \multicolumn{1}{c|}{} & 1. lista & 2. lista & 1. lista & 2. lista \\
\hline $\begin{array}{l}\text { Szkizofrén csoport } \\
(\mathrm{N}=15)\end{array}$ & $34 \%$ & $36 \%$ & \multicolumn{2}{c|}{} \\
\hline $\begin{array}{l}\text { Egészséges csoport } \\
(\mathrm{N}=115)\end{array}$ & $37 \%^{* *}$ & $53 \%$ & $69 \%$ & $54 \%^{* *}$ \\
\hline $\begin{array}{l}\text { CoNwAY és munkatársai }(2000) \\
\text { korábbi eredményei }\end{array}$ & $32 \%^{* *}$ & $51 \%$ & $67 \%$ & $49 \%^{* *}$ \\
\hline
\end{tabular}

$* * \mathrm{p}<0,01$ 
Mindez arra utal, hogy az instrukció ellenére a szkizofrén betegek nem voltak képesek intencionálisan elfelejteni az első lista szavait. Az 1. táblázat az összehasonlítás kedvéért tartalmazza korábbi egészséges személyekkel végzett irányított felejtési kísérleteink eredményeit is, bár ezek a csoportok egészséges egyetemi hallgatókból álltak, így intelligenciájukat és életkorukat tekintve nem számíthatóak illesztett kontrollcsoportnak, az összehasonlítás mégis tanulságos lehet. A táblázat adatai világosan mutatják, hogy - ellentétben a szkizofrén csoporttal - az egészséges kísérleti személyeknél a felejtési instrukció hatására megjelent az irányított felejtési hatás, vagyis az első lista szavait szignifikánsan kisebb számban idézték fel. A táblázatból az is világosan látszik, hogy a szkizofrén csoport emlékezeti teljesítménye általában véve alacsonyabb, mint az egészséges személyeké, aminek egyik oka éppen a fokozott interferencia-hatás lehet.

A 2. táblázatban láthatóak az elóhivás kiváltotta gátlás kísérlet eredményei. Az eredményekből egyértelmủen látszik, hogy az automatikus gátlás megjelent a szkizofrén csoport teljesítményében. Az egyszempontos ANOVA eredményei szerint szignifikáns eltérés mutatkozik a különböző csoportokba tartozó szavak felidézési teljesítményében $\underline{\mathrm{F}}(2,13)=40,69, \underline{\mathrm{p}}<0,001)$.

2. táblázat. Szkizofrén és egészséges személyekkel végzett előhívás kiváltotta gátláskísérletek felidézési eredményei

\begin{tabular}{|c|c|c|c|}
\hline & \multicolumn{2}{|c|}{ Gyakorolt kategóriából } & \multirow{2}{*}{$\begin{array}{l}\text { Nem gyakorolt ka- } \\
\text { tegóriából nem } \\
\text { gyakorolt elemek }\end{array}$} \\
\hline & gyakorolt elemek & $\begin{array}{c}\text { nem gyakorolt } \\
\text { elemek }\end{array}$ & \\
\hline $\begin{array}{l}\text { Szkizofrén betegek } \\
(\mathrm{N}=15)\end{array}$ & $63 \%$ & $22 \%^{* *}$ & $32 \%$ \\
\hline $\begin{array}{l}\text { Egészséges személyek } \\
(\mathrm{N}=115)\end{array}$ & $72 \%$ & $34 \%^{* *}$ & $42 \%$ \\
\hline
\end{tabular}

** $\mathrm{p}<0,01$

A gyakorolt kategóriák nem gyakorolt elemeiből szignifikánsan kevesebb elemet tudtak felidézni, mint a nem gyakorolt kategória szintén nem gyakorolt elemeiből, ez pedig Anderson és munkatársai elképzelésének megfelelően (ANDERSON, 1994; ANDERSON, SPELlman, 1995) az automatikus emlékezeti gátló mechanizmusok meglétét jelzi. A 2. táblázat tartalmazza 120 egészséges egyetemi hallgatóval végzett korábbi vizsgálatunk adatait is. Összehasonlítva a szkizofrén betegek eredményével láthatjuk, hogy bár a betegek általános teljesítménye alacsonyabb, a gátlás tekintetében nem maradnak alul az egészséges személyekkel szemben, míg a nem gyakorolt kategóriák nem gyakorolt elemeiből 32\%-ot idéztek fel, addig a gyakorolt kategóriák nem gyakorolt elemeiből 22\%-ot ( $\mathrm{p}<0,01)$. Ez a tízszázalékos különbség igen jelentős, ha meggondoljuk, hogy ezen elemek egyikét sem gyakorolták a személyek, a különbség csak annyi volt közöttük, hogy az egyik csoportba tartozó elemeknél a kategóriájukba tartozó más szavakat gyakoroltak. 
Összefoglalva: a szkizofrén betegekkel végzett vizsgálataink - összehasonlítva az egészséges személyektől nyert adatokkal - arra hívják fel a figyelmet, hogy az intencionális és az automatikus emlékezeti gátlás esetleg eltérő folyamatokat foglalhatnak magukban. A szkizofrén személyek, hasonlóan a depressziós (MATHEWS, MACLEOD, 1994; WENZLAFF, WEGNER, ROPER, 1988; WENZLAFF, WEGNER, KLEIN, 1991), valamint a poszttraumás zavarokban szenvedő betegekhez (MCNALLY, MetzGer, Lasko, PitMan, 1996) nem mutattak irányított felejtési hatást, vagyis nem tudták szándékosan frissíteni munkamemóriájuk tartalmát. Ezzel szemben az előhívás kiváltotta gátlás paradigma esetében a szkizofrén betegek az egészséges személyeket meghaladó mértékben mutattak emlékezeti gátló hatást. Ezt az eredményt sokféleképpen lehet értelmezni, elképzelhető, hogy az automatikus és az intencionális emlékezeti gátlás eltérő módon, esetleg eltérő idegrendszeri területek közreműködésével valósul meg. Egy másik lehetséges hipotézis, hogy maga a gátlás hasonló úton megy végbe, a különbség csak a gátlás automatikus vagy intencionális elindításában rejlik. Mindezeket a kérdéseket jövőbeni kísérleti és elektrofiziológiai vizsgálatainkban szeretnénk tisztázni.

\section{ÖSSZEFOGLALÁS}

Tanulmányunkban áttekintettük az emlékezeti gátlással kapcsolatos kísérleti és neuropszichológiai eredményeket. Természetesen sok mindenre nem tértünk ki, így például nem tárgyaltuk a figyelem kutatásánál használt kísérleti paradigmákat (negatív príming, Stroop-hatás stb.), amelyeknél sokan szintén gátlási folyamatokat tételeznek fel. Az emlékezeti frissítés neuropszichológiai szempontból talán legfontosabb kérdésének a végrehajtó funkciók működésében betöltött szerepe számít. A munkamemória aktuális tartalmának frissítésében elengedhetetlen szerepe van az emlékezeti gátlásnak, ennek pontos működése nélkül nehezen elképzelhető a központi végrehajtó koncepciójának adekvát továbbfejlesztése. Igyekeztünk bemutatni, hogyan használhatók a neuropszichológiai vizsgálatok során a kísérleti emlékezetkutatásban széles körben használt gátló paradigmák. A legrészletesebben két eljárást, az irányított felejtést és az előhívás kiváltotta gátlást ismertettük, majd bemutattuk saját vizsgálatunkat, amely során szkizofrén betegeknél néztük meg az automatikus és intencionális emlékezeti gátlás múködését. A vizsgálat alapján úgy tűnik, hogy a szkizofrén betegek számára nehézséget okoz intencionálisan gátlás alá helyezni munkamemóriájuk aktuális tartalmát, ugyanakkor az automatikus emlékezeti gátlás az egészséges szinten működik. További kutatásokat igényel annak tisztázása, hogy milyen viszonyban állnak egymással a különféle gátló paradigmák által működésbe léptetett folyamatok, milyen idegrendszeri területek aktiválódnak az egyes eljárások közben és pontosan mi a gátlás szerepe a végrehajtó funkciókat tesztelő eljárások sikeres kivitelezésénél. 


\section{IRODALOM}

Anderson, J. R., Bower, G. H. (1973) Human associative memory. D. C. Winston, Washington

Anderson, M. C., BJork, E. L., BJORK, R. A. (1994) Remembering can cause forgetting: retrieval dynamics in long-term memory. Journal of experimental Psychology: Learning, Memory, and Cognition, 20, 1063-1087.

Anderson, M. C., BJORK, R. A. (1994) Mechanisms of inhibition in long-term memory: a new taxonomy. In Dagenbach, D., Carr, T. H. (eds) Inhibitory Processes in Attention, Memory and Language. 265-327. Academic Press, San Diego

Anderson, M. C., Neely, J. H. (1996) Interference and inhibition in memory retrieval. In Bjork, E. L., Bjork, R. A. (eds) Memory. 237-318. Academic Press, San Diego

Anderson, M. C., Spellman, B. A. (1995) On the status of inhibitory mechanisms in cognition: memory retrieval as a model case. Psychological Review, 102, 68-100.

BADDELey, A. D. (1986) Working memory. Oxford University Press, Oxford

Baddeley, A. D., Hitch, G. J. (1974) Working Memory. In Bower, G. H. (ed.) Recent advances in learning and motivation. Vol. 8. Academic Press, New York

Baldo, J. V. Shimamura, A. P. (1998) Letter and category fluency in patients with frontal lobe lesions. Neuropsychology, 12, 259-267.

BAsden, B. H., BASDEn, D. R. (1996) Directed forgetting: A further comparison of the list and item methods. Memory, 4, 633-653.

Basden, B. H., Basden, D. R. (1998) Directed forgetting: A contrast of methods and interpretations. In Golding, J. M., MacLeod, C. M. (eds) Intentional Forgetting: Interdisciplinary Approaches. 139-173. Lawrence Erlbaum Associates, Mahwah

Basden, B. H., Basden, D. R., Gargano, G. J. (1993) Directed forgetting in implicit and explicit memory tests: A comparison of methods. Journal of Experimental Psychology: Learning, Memory, and Cognition, 19, 603-616.

Benson, D. F., Stuss, D. T. (1990) Frontal lobe influence on delusions: a clinical perspective. Schizophrenia Bulletin, 16, 403-411.

Berman, K. F., Illowsky, B., Weinberger, D. R. (1988) Physiological dysfunction of dorsolateral refrontal cortex in schizophrenia. IV. Further evidence for regional and behavioral specificity. Archives of General Psychiatry, 45, 616-622.

Berman, K. F., Torrey, E. F., Daniel, D. G., Weinberger, D. R. (1992) Regional cerebral blood flow in monozygotic twins discordant and concordant for schizophrenia. Archives of General Psychiatry, 49, 927-934.

BJORK, R. A. (1970) Positive forgetting: The noninterference of items intentionally forgotten. Journal of Verbal Learning and Verbal Behavior, 9, 255-268.

BJORK, R. A. (1989) Retrieval inhibition as an adaptive mechanism in human memory. In Roediger, H. L. Craik, F. I. M. (eds) Varieties of Memory and Consciousness: Essays in Honour of Endel Tulving. 309-330. Lawrence Erlbaum Associates, Hillsdale

BJORK, R. A. (1998) Intentional forgetting in perspective: comments, conjectures, and some directed remembering. In Golding, J. M., MacLeod, C. M. (eds) Intentional Forgetting: Interdisciplinary Approaches. 453-483. Lawrence Erlbaum Associates, Mahwah

BJork, R. A., LaBerge, D., Legrand, (1968) The modification of short-term memory through instructions to forget. Psychonomic Science, 10, 55-56. 
Burgess, P. W. (1997) Theory and methodology in executive function research. In Rabbitt, P. (ed.) Methodology of frontal and executive function. Psychology Press, Hove

Burgess, P. W., Shallice, T. (1996) Response suppression, initiation and frontal lobe lesions. Neuropsychologia, 34, 263-273.

Callicott, J. H., Ramsey, N., Tallent, K., Bertolino, A., Knable, M. B., Coppola, R., Goldberg, T., van Gelderen, P., Mattay, V. K., Frank, J., Moonen, T. W., WeinBERGER, D. R. (1998) 3-D PRESTRO fMRI of a working memory task in schizophrenia. Archives of General Psychiatry, 18, 186-196.

Cloitre, M. (1998) Intentional forgetting and clinical disorders. In Golding, J. M., MacLeod, C. M. (eds) Intentional forgetting: interdisciplinary approaches. 395-413. Lawrence Erlbaum Associates, London

Cloitre, M., Cancienne, J., Brodsky, B., Dulit, R., Perry, S. W. (1996) Memory performance among women with parental abuse histories: Enhanced directed forgetting or directed remembering? Journal of Abnormal Psychology, 105, 204-211.

Cockburn, J. (1995) Task interruption in prospective memory: A frontal lobe function? Cortex, 31, 87-97.

Conway, M. A., Harries, K., Noyes, J., Racsmány, M., Frankish, C. (2000) The disruption and dissolution of directed forgetting: inhibitory control of memory. Journal of Memory and Language, 43, 2, 409-430.

Conway, M., Howell, A., Giannopoulos, L. (1991) Dysphasia and thought suppression. Cognitive Therapy and Research, 15, 153-166.

CZIGLer I. (1988) A Ranschburg-effektus. Pszichológia, 8, 279-296.

CzIGler I. (2000) Ranschburg-effektus: megújult érdeklődés. Magyar Pszichológiai Szemle, 2-3, 297-304.

DSM-IV diagnosztikai kritériumai (1997) Animula Kiadó, Budapest

Eslinger, P. J., Damasio, A. R. (1985) Severe disturbance of higher cognition after bilateral frontal ablation: Patient EVR. Neurology, 35, 1731-1741.

Finkelhor, D., Browne, A. (1985) The traumatic impact of child sexual abuse: A conceptualization. American Journal of Orthopsychiatry, 55, 530-541.

FRITH, C. D. (1992) The cognitive neuropsychology of schizophrenia. Lawerence Erlbaum, Hove

FriTH, C. D. (1996) The role of the prefrontal cortex in self-consciousness: The case auditory hallucinations. Philosophical Transactions of the Royal Society, B351. 1505-1012. London

GERNSBACHER, M. A. (1990) Language comprehension as structure building. Erlbaum, Hillsdale

Gernsbacher, M. A. FAust, M. F. (1991) The mechanism of suppression: A component of general comprehension skill. Journal of Experimental Psychology: Learning, Memory, and Cognition, 17, 245-262.

Gernsbacher, M. A. Faust, M. F. (1995) Skilled Suppression. In Dempster, F. N. Brainerd, C. J. (eds) Interference and inhibition in Cognition. 295-327. Academic Press, San Diego

Glosser, G., Goodglass, H. (1990) Disorders in executive control functions among aphasic and other brain-damaged patients. Journal of Clinical and Experimental Neuropsychology, 12, 485-501. 
Gold, J. M., Berman, K. F., Randolph, C., Goldberg, T. E., Weinberger, D. R. (1996) PET validation and clinical application of a novel prefrontal task. Neuropsychology, 10, 310.

Goldstein, K. (1939) Clinical and theoretical aspects of lesions of the frontal lobes. Archives of Neurology and Psychiatry, 41, 865-867.

Hamm, V. P., Hasher, L. (1992) Age and availability of inferences. Psychology and Aging, 7, 56-64.

HARTMAn, M., HaSher, L. (1991) Aging and suppression: Memory for previously relevant information. Psychology and Aging, 6, 587-594.

Hasher, L., Zacks, R. T. (1988) Working memory, comprehension, and aging: A review and a new view. In Bower, G. H. (ed.) The Psychology of Learning and Motivation. Vol. 22. 193-225. Academic Press, San Diego

Herman, J. L. (1981) Father-daughter incest. Harvard University Press, Cambridge

KÉRI Sz., JANKa Z. (1999) Szkizofrénia neurokognitív modelljei, Magyar Pszichológiai Szemle, 4, 591-607.

KÉRI Sz., JANKA, Z. (2001) Kognitív és pszichofiziológiai zavarok szkizofréniában. Magyar Pszichológiai Szemle. (Előkészületben)

Leimkuhler, M. E., Mesulam, M. M. (1985) Reversible go-no go deficits in a case of frontal lobe tomour. Annals of Neurology, 18, 617-619.

Levin, H. S., Goldstein, F. C., Williams, D. H., EisenberG, H. M. (1991) The contribution of frontal lobe lesions to the neurobehavioral outcome of closed head head injury. In Levin, H. S., Eisenberg, H. M., Benton, A. L. (eds) Frontal lobe function and dysfunction. 318-338. Oxford University Press, New York

Lurija, A. R. (1973) The working brain. Penguin, London

Mathews, A., MacLeod, C. (1994) Cognitive approaches to emotional disorders. Annual Review of Psychology, 45, 25-50.

MCClelland, J. L. (1988) Connectionist models and psychological evidence. Journal of Memory and Language, 27, 107-123.

McClelland, J. L., Rumelhart, D. E. (1986) Parallel distributed processing. Vol. 2. MIT Press, Cambridge

McGeoch, J. A. (1936) Studies of retroactive inhibition: VII. Retroactive inhibition as a function of the length and frequency of presentation of the interpolated lists. Journal of Experimental Psychology, 19, 674-693.

McGeoch, J. A. (1942) The Psychology of Human Learning. Longmans, Green. New York

McNally, R. J., Metzger, L. J., Lasko, N. B., Pitman, R. K. (1996) Directed forgetting of trauma cues in women with histories of childhood sexual abuse. Manuscript. Under review.

Metzler, C., Parkin, A. J. (2000) Reversed negative priming following frontal lobe lesions. Neuropsychologia, 38, 363-379.

Milner, B. (1963) Effects of different brain lesions on card sorting. Archives of Neuorology, 9, 90-100.

Milner, B. (1964) Some effects of frontal lobectomy in man. In Warren, M. Akert, K. (eds) The frontal granular cortex and behavior. McGraw Hill, New York 
Norman, D. A., Shallice, T. (1986) Attention to action: willed and automatic control of behaviour. In Schwartz, G. E., Shapiro, D. (eds) Consciousness and self-regulation. Vol. 4. Plenum Press, New York

PAller, K. A. (1990) Recall and stem-completion priming have different electrophysiological correlates and are modified differentially by directed forgetting. Journal of Experimental Psychology: Learning, Memory, and Cognition, 16, 1021-1032.

RACSMÁny, M., Szendi, I., Conway, M. A. (2001) Intentional and automatic inhibition of memory processes. (Előkészületben)

Roberts, R. J., Hager, L. D., Heron, C. (1994) Prefrontal cognitive processes: Working memory and inhibition in the antisaccade task. Journal of Experimental Psychology, General, 123, 374-393.

Russel, D. E. H. (1986) The secret trauma: incest in the lives of girls and women. Basic Books, New York

Russo, R., ANDRADE, J. (1995) The directed forgetting effectin word-fragment completion: An applicationof the process dissociation procedure. Quarterly Journal of Experimental Psychology, 48A, 405-423.

Rylander, G. (1939) Personality changes after operations on the frontal lobes. Acta Psychiatrica Neurologica, Supplement No. 30.

SCHACTER, D. L. (1998) Emlékeink nyomában. Háttér Kiadó, Budapest

Shallice, T. (1982) Specific impairments of planning. Philosophical Transactions of the Royal Society, B298. 199-209. London

Shallice, T. (1988) From neurospsychology to mental structure. Cambridge University Press, Cambridge

Shallice, T., Burgess, P. W. (1991) Deficits in strategy application following frontal lobe damage in man. Brain, 114, 727-741.

Shallice, T., Burgess, P. W. (1998) The domain of supervisory processes and the temporal organization of behaviour. In Roberts, A. C., Robbins, T. W., Weiskrantz, L. (eds) The prefrontal cortex: Executive and cognitive functions. 22-36. Oxford University Press, Oxford

Shallice, T., Evans, M. E. (1978) The involvement of the frontal lobes in cognitive estimation. Cortex, 14, 294-303.

Shimamura, A. P. (1989) Disorders of memory: The cognitive science perspective. In Boller, F. Grafman, J. (eds) Handbook of neuropsychology. Vol. 3. Elsevier, Amsterdam

Shimamura, A. P. (1995) Memory and frontal lobe function. In Gazzaniga, M. (ed.) The cognitive neurosciences. 803-813. MIT Press, Cambridge

Shimamura, A. P., Janowsky, J. S., Swuire, L. R. (1991) What is the role of frontal lobe damage in memory disorders? In Levin, H. S., Eisenberg, H. M., Benton, A. L. (eds) Frontal lobe function and dysfunction. 173-195. Oxford University Press, New York

SLAmeckA, N. J. (1968) An examination of trace storage in free recall. Journal of Experimental Psychology, 76, 504-513.

SlameckA, N. J. (1972) The question of associative growth in the learning of categorized materials. Journal of Verbal Learning and Behavior, 11, 324-332.

SLAmeckA, N. J. (1975) Intralist cueing of recognition. Journal of Verbal Learning and Behavior, 14, 630-637. 
STuss, D. T. (1991) Interference effects on memory functions in postleukotomy patients: an attentional perspective. In Levin, H. S., Eisenberg, H. M., Benton, A. L. (eds) Frontal lobe function and dysfunction. 157-172. Oxford University Press, New York

Stuss, D. T., Alexander, M. P., Hamer, L., Palumbo, C., Dempster, R., Binns, M., LEvine, B., IzUkAwA, D. (1998) The effects of focal anterior and posterior brain lesions on verbal fluency. Journal of the International Neuropsychological Society, 4, 265-278.

Wegner, D. M. (1989) White bears and other unwanted thoughts. Viking/Penguin, New York

Wegner, D. M. (1994) Ironic processes of mental control. Psychological Review, 101, 1, 34 52.

Weinberger, D. R., Berman, K. F. (1998) Prefrontal function in schizophrenia: confounds and controversies. In Roberts, A. C., Robbins, T. W., Weiskrantz, L. (eds) The prefrontal cortex: Executive and cognitive functions. 165-181. Oxford University Press, Oxford

Weinberger, D. R., Berman, K. F., Zec, R. F. (1986) Physiological dysfunction of dorolateral prefrontal cortex in schizophrenia. I. Regional cerebral blood flow (rCBF) evidence. Archives of General Psychiatry, 43, 114-125.

WEINER, B., REED, H. (1969) Effects of the instructional sets to remember and to forget on short-term retention: studies on rehearsal control and retrieval inhibition (repression). Journal of Experimental Psychology, 79, 226-232.

Wenzlaff, R. M., Wegner, D. M, Roper, D. (1988) Depression and mental control. The resurgence of unwanted negative thoughts. Journal of Personality and Social Psychology, 55, 882-892.

Wenzlaff, R. M., Wegner, D. M., Klein, S. B. (1991) The role of thought suppression in the bonding of thought and mood. Journal of Personality and Social Psychology, 60, 500508 .

Wilhelm, S., McNally, R. J., Baer, L., Florin, I. (in press) Directed forgetting in obsessive-compulsive disorder. Behaviour Research and Therapy.

Williams, L. M. (1994) Recall of childhood trauma: A prospective study of women's memories of childhood sexual abuse. Journal of Consulting and Clinical Psychology, 62, 1167-1176.

Wilson, B. A., Alderman, N., Burgess, P. W., Evans, J. J. (1996) Behavioural Assessment of the Dysexecutive Syndrome. Thames Valley Test Company, Bury St. Edmunds

WoOdward, A. E., JR., BJork, R. A. (1971) Forgetting and remembering in free recall: Intentional and unintentional. Journal of Experimental Psychology, 89, 109-116.

WoOdward, A. E., JR., BJORK, R. A., JONGEWARD, R. H., JR. (1973) Recall and recognition as a function of primary rehearsal. Journal of Verbal Learning and Verbal Behavior, 12, 608-617.

Yehuda, R., Keefe, R. S. E., Harvey, P. D., Levengood, R. A., Gerber, D. K., Geni, J., SIEVER, L. J. (1995) Learning and memory in combat veterans with post traumatic stress disorders. American Journal of Psychiatry, 152, 137-139.

ZACKS, R. T., HASHER, L. (1988) Capacity theory and the processing of inferences. In Light, L. L., Burke, D. M. (eds) Language, Memory, and Aging. 154-170. Cambridge University Press, New York

Zacks, R. T., HASHER, L. (1994) Directed ignoring: Inhibitory regulation of working memory. In Dagenbach, D., Carr, T. H. (eds) Inhibitory processes in Attention, Memory, and Language. 241-263. Academic Press, San Diego 


\title{
"DON'T THINK OF THE WHITE BEAR" \\ THE NEUROPSYCHOLOGY OF INHIBITORY PROCESSES IN MEMORY
}

\author{
RACSMÁNY, MIHÁLY-SZENDI, ISTVÁN
}

The paper surveys different methodological approaches of executive function research and outlines the role of memory inhibition in flexible planning and problem solving. We present a detailed analysis of inhibitory paradigms used in memory research: directed forgetting, thought suppression and retrieval induced forgetting, and their possible adaptation for neuropsychological investigation. Our paper reviews the evidences concerning the consequences of memory inhibition disorders in depression, posttraumatic stress disorder and panic disorder. Finally, we present our study regarding automatic and intentional inhibitory functions in schizophrenia.

Key words: executive functions, working memory, prefrontal cortex, memory inhibition, schizophrenia 